\title{
Perícia criminal: uma abordagem de serviços
}

\section{Forensic science: a service approach}

\author{
Cláudio Vilela Rodrigues ${ }^{1}$ \\ Márcia Terra da Silva² \\ Oswaldo Mário Serra Truzzi ${ }^{3}$
}

\begin{abstract}
Resumo: O objeto deste artigo é o serviço de perícia criminal e seu principal objetivo é argumentar que o enquadramento das atividades desenvolvidas pela perícia criminal como um processo de operações em serviço que ocorre em uma rede interorganizacional pode incrementar o valor da imparcialidade da Justiça Criminal entregue a seus principais destinatários. Tomando-se o serviço de perícia criminal em Minas Gerais como estudo de caso, analisou-se o valor a partir da perspectiva das consequências para os destinatários e dos recursos utilizados para produzi-las. Como resultado, obteve-se que a utilidade do serviço de perícia criminal é produzir a prova da materialidade do crime e vincular o autor à cena do crime e, assim, contribuir para a elucidação do delito. $\mathrm{O}$ valor do serviço foi definido considerando as condições de acesso para todos os envolvidos, principalmente para os segmentos excluídos da sociedade. Avaliou-se também a inclusão social que, no serviço de perícia criminal, traduz-se na investigação de delitos, sem que seja necessário submeter os suspeitos a constrangimentos. Concluiu-se que a perícia criminal é um meio para a realização do valor de imparcialidade da Justiça e as competências dos peritos constituem seu principal recurso. Este artigo permite refletir sobre as dificuldades de aplicar conceitos de gestão de serviços a uma organização pública com diversidade de públicos e com valor fluido e pouco definido, porém importante, como esta.
\end{abstract}

Palavras-chave: Perícia criminal. Valor de serviço público. Gestão de operações de serviços.

\begin{abstract}
This paper addresses forensic science service, and its main goal is to argue that considering forensic science activities as a service operations process that takes place in an interorganizational network might increase the impartiality of the Criminal Justice system delivered to its main customers. The service in Minas Gerais/BRA State was taken as a case study. We analyzed the value of this service from the perspective of the customers and the necessary resources to deliver it. The results indicate that, as it is conceived, this service includes the production of evidences that link the suspect to the crime scene contributing to clarify an event. The value of the service necessarily takes into account that everyone has a right of access to justice, especially the excluded strata. It was also evaluated the dimension of social inclusion which, in this service, means to support crime investigation without being embarrassing or harassing suspects. We conclude that the Forensic Science service is a means to practice and improve the impartiality of Justice as a value and that the forensic scientist competence is the main resource to reach it. This paper encourages reflections about the difficulties of applying service management concepts to a public organization characterized by the diversity of customers and by its fluid and poorly defined, although important, value such as the Criminal Justice system.
\end{abstract}

Keywords: Forensic science. Public services value. Public services operations management.

\section{Introdução}

A redemocratização do Brasil, principalmente após a promulgação da Constituição de 1988, previu aos cidadãos direitos e garantias individuais, tais como o direito de se calar durante o interrogatório policial e a preservação da incolumidade física da pessoa. Ao mesmo tempo, a criminalidade cresceu e, de uma forma ou de outra, atinge todo o País. Brasileiros, entrevistados em pesquisas de opinião pública, apontam a violência como o principal problema do País (VIOLÊNCIA..., 2007). Assim, no Estado Democrático de Direito é preciso conciliar o respeito aos direitos humanos com uma investigação eficaz

\footnotetext{
${ }^{1}$ Departamento de Engenharia de Produção, Universidade Federal de São Carlos - UFSCar, Polícia Civil/MG, Av. Deputado Renato Azeredo, n. 1342, Bairro Dom Pedro II, CEP 37410-000, Três Corações - MG, E-mail: claudiovilela@ dep.ufscar.br

2 Departamento de Engenharia de Produção, Escola Politécnica da Universidade de São Paulo - USP, Av. Prof. Almeida Prado, travessa 2, n. 128, CEP 05508-070, Cidade Universitária, São Paulo - SP, E-mail: mtdsilva@ usp.br

${ }^{3}$ Departamento de Engenharia de Produção, Centro de Ciências Exatas e Tecnologia, Universidade Federal de São Carlos UFSCar, Rod. Washington Luís, Km. 235, CEP 13565-905, São Carlos - SP, E-mail: truzzi@ ufscar.br
}

Recebido em 26/11/2008 — Aceito em 8/10/2010

Suporte financeiro: Nenhum. 
dos crimes, de forma a levar os seus autores às barras dos tribunais e propiciar um julgamento justo.

É neste contexto que a perícia criminal adquire importância, como o segmento responsável pela produção da prova pericial, usando como fonte de seu trabalho o conhecimento científico e as inovações tecnológicas aplicadas.

Desde 1995, a administração pública no Brasil busca construir um Estado gerencial (BRESSER PEREIRA, 2004; MARCELINO, 2003; SAINTMARTIN, 2004; MATIAS-PEREIRA, 2008), com práticas preconizadas pela Nova Gestão Pública (HOOD, 1991) e/ou o governo empreendedor (OSBORNE; GAEBLER, 1992). Em Minas Gerais, o governo estadual tem como plataforma política o "Choque de Gestão" (MINAS GERAIS, 2004), cujas bases preconizam novas filosofias gerenciais, que repercutem nos órgãos de segurança pública. Aproveitando-se destas novas abordagens e corroborando-as, Starr (2005) e Slack (2005) propõem que a engenharia de produção amplie o seu escopo para serviços, incluindo os de saúde e segurança públicas, sob pena de ficar restrita a um "gueto": a manufatura.

Sob esta perspectiva, há várias ferramentas da engenharia de produção que poderiam ser aplicadas no serviço analisado. Entre elas, as de qualidade do serviço e as de medição de eficiência e eficácia (CAULLIRAUX; PROENÇA, 2004). Do ponto de vista da abordagem organizacional, é necessário conhecer o valor do serviço pesquisado, para discutir as formas de organizar a produção do serviço (ZARIFIAN, 2001b). Como o uso da terminologia 'cliente' em serviços públicos é controverso (CAULLIRAUX; YAMASHITA, 2004; ZARIFIAN, 2001a) e nesta rede de produção de valor, os demandantes do serviço de perícia criminal são outros prestadores de serviço, que atenderão ao usuário final, optou-se pelo termo destinatário (do serviço).

Coerente com este momento da administração pública, o objetivo geral deste artigo é argumentar que o enquadramento das atividades desenvolvidas pela perícia criminal como um processo de operações em serviço que ocorre em uma rede interorganizacional pode incrementar o valor da imparcialidade da Justiça Criminal entregue a seus principais destinatários. Para analisar esta operacionalização, surge uma questão central: Qual o valor do serviço de perícia criminal para os principais destinatários desse serviço? Os objetivos específicos são:

- Caracterizar o ambiente geral, a rede interorganizacional e a operação do serviço.

- Mapear os principais públicos do serviço.

- Descrever o macroprocesso de produção e definir o tangível e o intangível neste serviço.

- Identificar o que é valor para os principais destinatários de um serviço destinado a produzir insumo para um valor básico de Justiça.
- Contribuir para a aplicação da engenharia de produção em serviços públicos.

$\mathrm{O}$ presente artigo se justifica, porque, em primeiro lugar, os governos e suas respectivas agências devem criar valor para a sociedade (KIRLIN, 1996). Outra razão é que as novas abordagens gerenciais da administração pública sustentam que os serviços públicos devem atender às necessidades dos públicos e não da burocracia (OSBORNE; GAEBLER, 1992). Pesquisar o que é valor para o destinatário do serviço é o primeiro passo, para organizar a produção com eficiência. Para isso, é preciso conhecer os problemas enfrentados pelo destinatário do serviço em sua atividade. Este conhecimento se dá por meio de uma competência e do estabelecimento de uma relação dialógica entre o prestador e o destinatário. De fato, somente a partir da definição do que é valor para o(s) destinatário(s), é possível se perseguir a eficiência na utilização dos recursos, principalmente, dos recursos humanos.

Esta eficiência consiste em "[...] mobilizar 'corretamente' seus recursos para gerar as consequências esperadas." (ZARIFIAN, 2001b, p. 135), ou seja, em alocar os recursos de forma a atender às consequências esperadas pelos diferentes públicos do serviço no que concerne à utilidade, à justiça, à solidariedade e à estética, mas com economia no uso. Esta racionalização com relação às consequências exige

[...] todo um raciocínio sobre as formas organizacionais e sobre o desenvolvimento de competências e de cooperação interna na empresa para, simultaneamente, mobilizar os recursos adequados, e economizá-los em seu uso. (ZARIFIAN, 2001b).

Neste contexto, a competência profissional é o principal recurso, tanto para entender as expectativas e definir o que é valor para o destinatário quanto para alocar os recursos necessários com eficiência no uso, para entregar valor.

O artigo apresenta, além desta introdução e da metodologia, o ambiente e a rede em que a perícia criminal está inserida, para, então, identificar os seus respectivos públicos e, consequentemente, os destinatários do serviço. Em seguida, mostrou-se o processo de produção do serviço, no qual são ressaltadas as características de tangibilidade e intangibilidade. A partir destes tópicos, abordou-se o valor do serviço, sob a perspectiva das consequências e dos recursos. Ao final, emitem-se as conclusões.

\section{Metodologia}

O trabalho partiu do conceito de que a estrutura da rede de segurança pública e justiça criminal existente em cada ente federado (União, Estados e 
Distrito Federal) constituem os limites institucionais do serviço de perícia criminal. Assim, o serviço de perícia criminal em Minas Gerais foi considerado como um estudo de caso único com várias unidades de análise, ou "[...] estudo de caso incorporado." (YIN, 2005, p. 61), entre os demais existentes. O levantamento de dados foi realizado no período de 1 de junho de 2004 a 30 de julho de 2008.

Segundo Cauchick Miguel (2010, p. 129), o estudo de caso é um

[...] trabalho de caráter empírico que investiga um dado fenômeno dentro de um contexto real contemporâneo por meio de análise aprofundada de um ou mais objetos de análise.

O estudo de caso foi a abordagem escolhida, principalmente, devido à natureza exploratória da questão de pesquisa, além da investigação dizer respeito a acontecimentos contemporâneos (YIN, 2005)

$\mathrm{O}$ arranjo institucional da perícia criminal ainda está em construção no País, havendo estruturas subordinadas à Polícia e outras autônomas, muitas atravessando mudanças. O caráter pouco definido da estrutura do serviço confirma a sua contemporaneidade e reforça a necessidade do estudo de caso para entender a sua dinâmica.

Após a revisão bibliográfica, foram utilizadas seis “[...] fontes de evidências." (YIN, 2005, p. 111-124) admitidas em estudos de caso. Uma pesquisa documental na legislação correlata e nos sítios do Tribunal de Justiça, do Ministério Público e da Polícia Civil, todos de Minas Gerais, teve por objetivo corroborar evidências oriundas de outras fontes e identificar a rede em que o serviço está inserido. A segunda fonte de evidências consultada foram os registros nos arquivos do órgão pesquisado, contendo dados relativos ao período entre 2000 e 2007. São informações essenciais para compor as análises sobre o volume, a variedade, a capacidade e a organização do serviço. Constituíram a terceira fonte de evidências entrevistas com: dois juízes, um promotor de justiça, um defensor público, um delegado de polícia, o Diretor do Instituto de Criminalística, os quais possuíam mais de dez anos de exercício em sua respectiva atividade cada um, escolhidos por conveniência, pela experiência na área criminal e pelo conhecimento das respectivas instituições em que atuam, constituindo-se nos “[...] informantes-chave." (YIN, 2005, p. 117; WEISS, p. 20); além de peritos de 16 unidades da federação e também seis vítimas e/ou parentes de envolvidos em ocorrências. A finalidade das entrevistas foi a de mapear os públicos, conhecer a atividade, explorar o valor do serviço e capturar diferentes visões. A quarta fonte utilizada foi a observação direta: no Instituto de Criminalística/MG, a fim de se mapear processos da prestação do serviço e observar as instalações; em cinco Seções Regionais de Criminalística no interior do Estado; e de um júri popular de três acusados de matar e estuprar uma mulher, para avaliar o papel da perícia criminal no júri. O primeiro autor fez observações participantes, como quinta fonte de evidência. Por fim, buscaram-se "[...] artefatos físicos." (YIN, 2005, p. 124), principalmente os tecnológicos usados na prestação do serviço.

Adicionalmente, esclarece-se que o primeiro autor é perito criminal da Polícia Civil/MG. Na pesquisa e respectiva análise, buscou-se uma "ruptura objetivante" (PINTO, 1998), ou seja, propôs-se manter o distanciamento necessário a um trabalho científico. Entretanto, o primeiro autor utilizou a sua experiência pessoal na pesquisa, fato comum no estudo de caso (YIN, 2005). A pesquisa apresenta as dificuldades de generalização, típica das pesquisas qualitativas, mas revela insights decisivos, dificilmente discerníveis em análises de cunho mais generalizantes.

\section{$3 \mathrm{O}$ ambiente geral e a rede interorganizacional da perícia criminal}

Em Minas Gerais, a Superintendência de Polícia Técnico-Científica (SPTC) é chefiada por um perito criminal ou médico legista, subordinada diretamente à Chefia de Polícia Civil e integrante do Conselho Superior da Instituição. A SPTC abriga os serviços de perícia criminal (criminalística) e medicina-legal. A medicina-legal é composta essencialmente por médicos-legistas, que procedem às necropsias em cadáveres, em situações de morte violenta, tais como homicídios, suicídios e acidentes. Realizam também exames de corpo delito em pessoas vivas, que foram alvo de alguma violência, ou acidente, e também testes de alcoolemia, por exemplo. O foco deste artigo é o serviço de perícia criminal, responsável por examinar locais de crime, coletar e analisar vestígios deixados em infrações penais.

\subsection{O papel da perícia criminal no ambiente legal}

Dentro do arcabouço legal, é de fundamental importância o $\operatorname{artigo} 5^{\circ}$ da Constituição Federal, que prevê os direitos e garantias individuais dos cidadãos, entre os quais se destacam que: ninguém será submetido à tortura; as provas obtidas por meios ilícitos são inadmissíveis; a pessoa que for presa será informada de seus direitos, entre os quais o de permanecer calada e o de ter a assistência da família e de advogado. Estes direitos e garantias individuais representam a objetivação da concepção social e política de que a polícia não pode mais utilizar métodos arcaicos de investigação, como a tortura, por exemplo. É neste contexto que a prova pericial, produzida com base científica, ganha relevância, 
colaborando para promover o respeito aos direitos humanos nas investigações, conforme afirma um promotor público:

Com a evolução da teoria dos direitos humanos, não dá para pendurar o cara para ele confessar. Porque se me pendurar eu confesso qualquer coisa que quiser: fui eu que explodi as torres gêmeas de Nova Iorque. Confesso, assino. Tem valor? Não. Chega lá, a gente passa vergonha. O que sobra? Polícia Científica. Quanto mais o mundo evolui no sentido de preservar os direitos da cidadania, os direitos humanos das pessoas tanto mais relevante se torna a Polícia Científica. Porque nós não podemos deixar de incriminar quem praticou crimes, sob pena da sociedade ficar desprotegida. Mas temos que fazê-lo através das técnicas científicas. Então, a Polícia Científica é a única e a maior solução para a problemática do processo criminal e da atuação criminal de todos os países [...] O futuro da polícia é a Polícia Científica. Não existe saída fora da Polícia Científica. Quanto mais ela aprimorar, quanto mais técnicas, quanto mais ela for presente, tanto menos injustiças, tanto menos lesões aos direitos humanos, à cidadania e tanto mais. A importância da Polícia Científica é primordial. (Promotor de Justiça, grifo nosso).

A atividade pericial é regulada pelo Código de Processo Penal (CPP). Os peritos são classificados como auxiliares da justiça (CÓDIGO..., 2005, art. 275), com conhecimento especializado em determinada área, sujeitos à disciplina judiciária e aos mesmos impedimentos dos juízes (CÓDIGO..., 2005, art. 280). A perícia está inserida no título das provas (CÓDIGO..., 2005, art. 158-250), que são dez: pericial; interrogatório do acusado; confissão; perguntas à vítima; testemunhal; reconhecimento de pessoas ou coisas; acareação; documental; indiciária; e busca e apreensão. No processo penal prevalece o princípio da verdade real, em que "[...] o juiz tem o dever de investigar como os fatos se passaram na realidade." (CAPEZ, 2003, p. 26). No processo civil prevalece a verdade formal, que "[...] emerge no processo, conforme os argumentos e as provas trazidas pelas partes.” (NUCCI, 2006, p. 362).

Perícia é

[...] o exame de algo ou alguém realizado por técnicos ou especialistas em determinados assuntos, podendo fazer afirmações ou extrair conclusões pertinentes ao processo penal. (NUCCI, 2006, p. 367).

Perito é

[...] o apreciador técnico, assessor, do juiz com a função de fornecer dados instrutórios de ordem técnica e proceder à verificação e formação do corpo de delito. (MIRABETE, 2000, p. 420).

O exame de corpo de delito é "[...] a verificação da prova da existência do crime." (NUCCI, 2006, p. 366). A perícia criminal é obrigatória nas infrações penais que deixarem vestígios (CÓDIGO..., 2005, art. 158), sob pena de nulidade do processo (CÓDIGO..., 2005, art. 564, III, b), não sendo suprida nem pela confissão do acusado. Vestígio "[...] é o rastro, a pista ou o indício deixado por algo ou alguém.” (NUCCI, 2006, p. 366), que, ao final dos exames periciais, poderá se constituir em uma prova. Deve ser realizada por perito oficial (vinculado ao Estado), que ao final emite um laudo pericial. A parte das provas envolve várias questões jurídicas, que fogem ao escopo deste trabalho.

\subsection{A rede interorganizacional}

A análise das redes interorganizacionais " [...] foca na complexa rede de relações em que um grupo de organizações está inserido." (HATCH; CUNLIFFE, 2006, p. 66), para produzir um valor. Analisa-se a posição relativa de cada integrante, bem como o fluxo de informações, recursos, conhecimentos, oportunidades e influências. Além da complexidade da relação, cada integrante da rede tem suas próprias prioridades.

A perícia criminal integra uma rede constituída para entregar um valor básico de Justiça, composta por um ciclo judicial e outro policial. No primeiro, estão o Poder Judiciário e as funções essenciais da justiça (Ministério Público, Advocacia, Advocacia Pública e Defensoria Pública). O Poder Judiciário, cuja função é aplicar a lei ao caso concreto, é constituído por tribunais federais, estaduais e do distrito federal, que atuarão de acordo com o caso. O serviço é prestado por juízes e serventuários da justiça (BRASIL, 1988, art. 92-126). O sistema de segurança pública (ciclo policial) é constituído por: polícia federal; polícias rodoviária e ferroviária federal; polícias civis e militares, e corpos de bombeiros militares estaduais, e guardas-municipais (BRASIL, 1988, art. 144).

Caulliraux et al. (2004) e Caulliraux, Proença e Lyra Da Silva (2004) mapearam e sequenciaram os macroprocessos desta rede, enfatizando os serviços das Polícias Civil e Militar. Aqui, foram destacadas as principais atividades de cada ator ao longo da rede. Resumidamente (Figura 1), quando há um crime, a Polícia Militar ou Rodoviária é chamada, vai ao local, isola-o e aciona a Polícia Civil, que, então, o assume, preserva-o, requisita a perícia e inicia a investigação. A perícia criminal realiza o seu trabalho, libera o local, e ao final elabora um laudo pericial que integrará o inquérito policial. Durante a investigação, a Polícia Civil busca suspeitos e testemunhas, ouve pessoas, etc. Ao final, o delegado elabora um relatório para o juiz de direito, que o repassa ao promotor de justiça. Este 


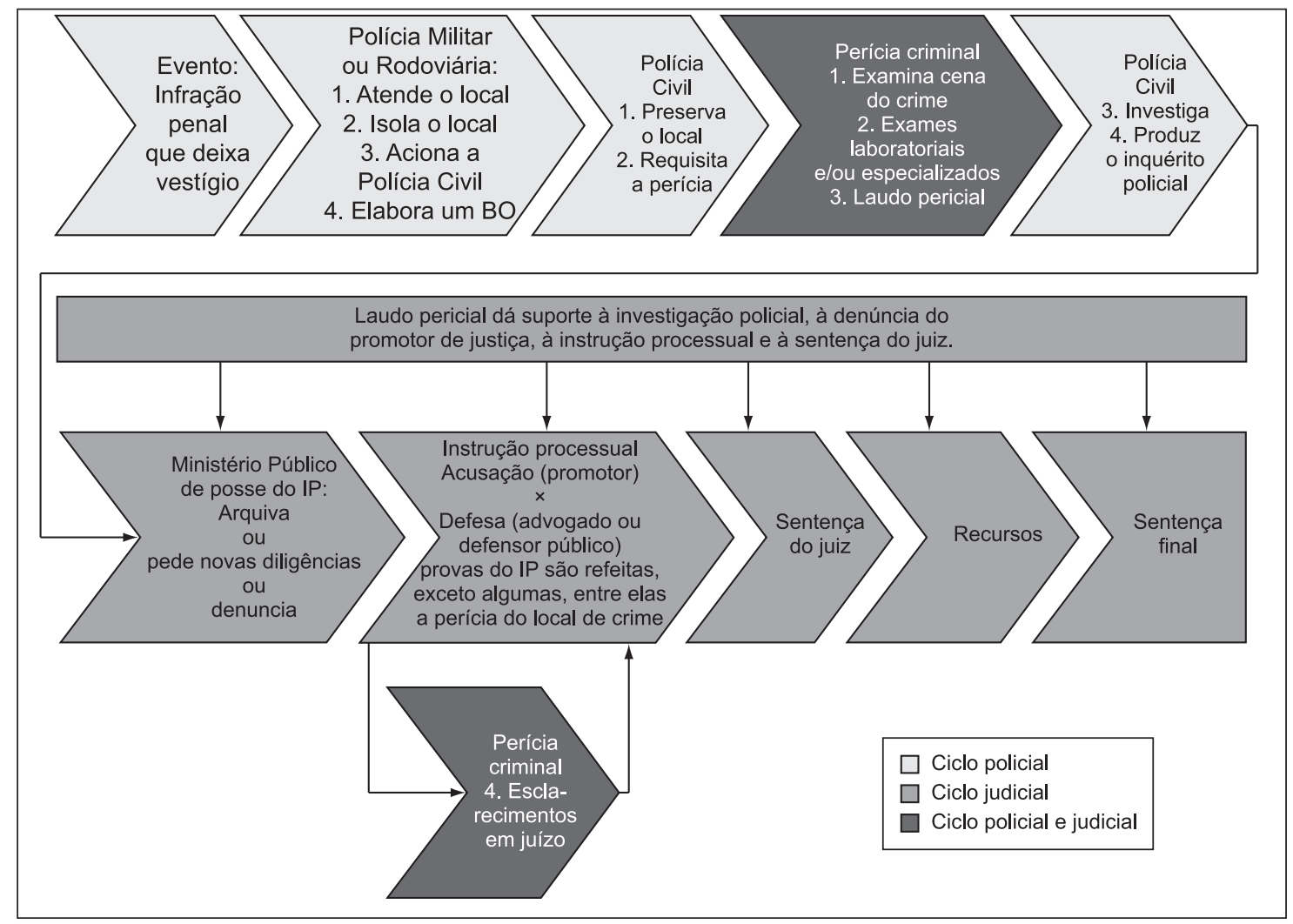

Figura 1. Macroprocesso simplificado do evento até a sentença final. Fonte: Elaborada pelos autores.

denuncia, pede arquivamento ou complementação. Oferecida e aceita a denúncia, inicia-se a instrução processual dirigida pelo juiz. O promotor e o advogado de defesa apresentam provas, arguem testemunhas, debatem, etc. Nesta fase, as provas produzidas no inquérito policial são refeitas, exceto algumas, entre elas o levantamento pericial realizado no local do crime. Após a instrução, o juiz dá a sentença, da qual cabem recursos. Quando não couberem mais recursos, cumpre-se a sentença e encerra-se o caso.

Do ponto de vista da perícia criminal, a participação nesta rede exige que ela se relacione com atores distintos, de diferentes instituições, os quais têm suas próprias prioridades. O fluxo mais intenso de informações e materiais é com a Polícia Civil, pois é o delegado de polícia quem requisita a perícia. Há também o fluxo de informações com o Poder Judiciário, sempre que os juízes requisitam exames e/ou laudos para instruir o processo ou, ainda, respostas a quesitos escritos ou o comparecimento do perito em juízo.

A rede entrega um valor de Justiça, que promove a pacificação social, evitando que as pessoas façam justiça com as próprias mãos. Entrega a aqueles que tiveram seus direitos violados uma compensação intangível e, ao mesmo tempo, faz com que, os que ofenderam a lei, respondam e paguem pelos seus atos. O principal usuário final desta rede é a sociedade como um todo, para quem o valor de serviço é a imparcialidade da Justiça. A perícia criminal contribui para esse valor com um insumo - a prova material ou pericial.

\subsection{Os diversos públicos do serviço de perícia criminal}

A perícia criminal lida com diversos públicos. Um público "[...] consiste de grupos e organizações que tenham algum interesse nas atividades da organização foco." (ANDREASEN; KOTLER, 2007, p. 75). Estes públicos podem ser classificados em: destinatários internos, que

[...] são parte da mesma organização, mas de diferentes unidades ou operações., e externos, que são [...] pessoas ou grupo de pessoas externas à organização, que estão recebendo o serviço. (JOHNSTON; CLARK, 2005, p. 72)

stakeholders: financiadores, beneficiários ou participantes (JOHNSTON; CLARK, 2005). Seguindo-se o proposto por Caulliraux e Yamashita (2004), os principais públicos da perícia criminal foram mapeados, conforme ilustra a Figura 2. 
A variabilidade de públicos externos com os quais a organização mantém relacionamento de serviço induz a um aumento de complexidade da tarefa, pois cada público tem um interesse no serviço demandado e parte de um conjunto de critérios para avaliá-lo. Pode-se dizer que o resultado almejado do serviço da perícia criminal é diferente para cada um dos seus públicos, de forma que o esforço da organização para definir o valor do serviço pode ser entendido como uma forma de integrar as diferentes visões que permeiam as operações (JOHNSTON; CLARK, 2005).

Em serviços com a diversidade de públicos e distribuição geográfica da perícia criminal, muitas vezes, mesmo os destinatários internos do serviço, como o delegado de polícia, partem de visões e interesses diferentes daqueles presentes na organização estudada. Os relacionamentos com estes diversos públicos induzem a diferentes pressões na linha de frente, porque eles têm demandas diversas. Assim, por exemplo, um parente de uma vítima quer que o trabalho da perícia na cena do crime seja meticuloso e longo, enquanto os policiais, que provavelmente têm outros casos para atender, preferem-no breve. É comum ainda que vítimas e/ou familiares e os suspeitos apresentem interesses contraditórios.

O laudo pericial é essencial para que os promotores de justiça peçam o arquivamento do inquérito policial, ou ofereçam denúncia contra alguém, pois a denúncia depende da prova de que o crime existiu (materialidade) e indícios de autoria. Como os peritos criminais e os promotores de justiça são de instituições distintas, estes são destinatários externos do serviço.

Dentre os públicos da Figura 2, ressalta-se o papel do juiz de direito, um destinatário externo do serviço. Como mostra a Figura 1, o juiz dirige o ciclo judicial e profere a sentença e, portanto, entrega o valor final desta rede interorganizacional. Para que a tarefa do juiz seja cumprida, ele precisa de informações estruturadas para aplicar a lei ao caso concreto e a perícia criminal contribui com as provas materiais, legitimadas pela ciência.

Os beneficiários da perícia são aqueles que de alguma forma se beneficiam do serviço. A sociedade como um todo tem interesse em uma Justiça Criminal que encontre e puna os responsáveis por delitos cometidos (ou inocente aqueles erroneamente acusados), e ao mesmo tempo respeite os direitos humanos. A perícia contribui para este anseio da sociedade com provas científicas que ajudam a Polícia e a Justiça Criminal, respectivamente, a identificar e julgar os verdadeiros autores dos delitos. Outros beneficiários são a vítima e/ou seus familiares, porque a perícia criminal auxilia a esclarecer o fato; os suspeitos, à medida que não é necessário constrangê-los durante as investigações; os advogados de defesa, que utilizam as informações da perícia para formular as estratégias de defesa dos seus clientes; as testemunhas, à medida que a perícia ajuda a confirmar os depoimentos (ou desmenti-los); a mídia, à medida que repercute os casos, dando-lhes uma maior ou menor dimensão, e ao mesmo tempo precisa informar a opinião pública

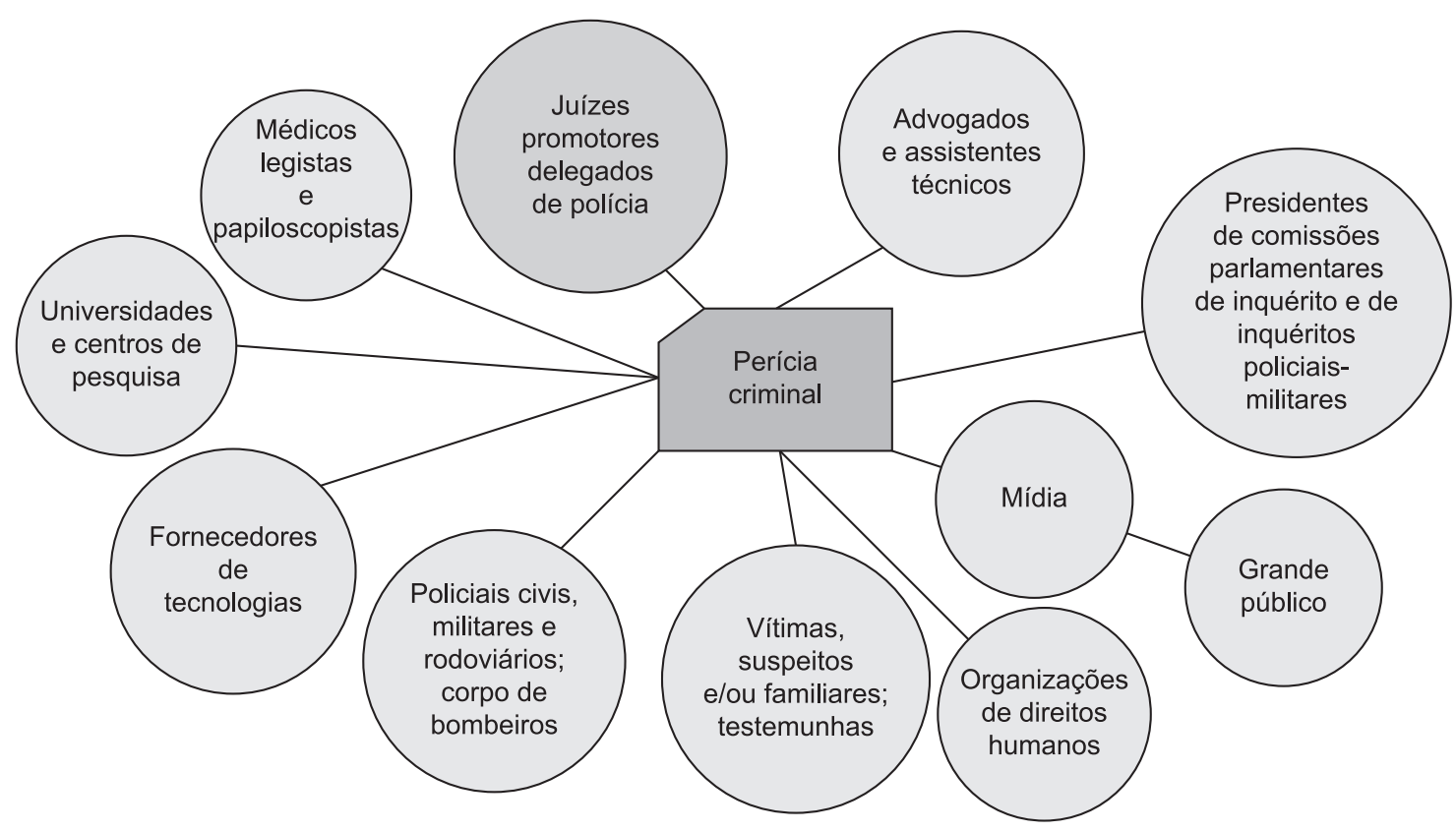

Figura 2. A perícia criminal e os seus principais públicos. Inspirado em Andreasen e Kotler (2007), Caulliraux e Yamashita (2004) e Johnston e Clark (2005). 
com maior precisão; e as organizações de direitos humanos, que utilizam os laudos periciais, para avaliar ações policiais, por exemplo.

São participantes do serviço: os suspeitos, a vítima e/ou seus familiares e, eventuais testemunhas, porque, em alguns casos, eles fornecem informações e padrões para diversos exames; os policiais (civis, militares ou rodoviários) e/ou bombeiros, porque atuam no isolamento e na preservação da cena do crime, que é quando todo o processo começa; os fornecedores de material de consumo e, principalmente, de novas tecnologias que auxiliem no trabalho dos peritos; as universidades, com o conhecimento científico; os médicos legistas que trocam informações com os peritos criminais; e os papiloscopistas (setor de Identificação Civil e Criminal) que auxiliam na identificação de pessoas.

A definição dos vários públicos e do valor que cada um confere ao serviço diminui a ênfase dada a uma determinada concepção e equilibra a operação (CAULLIRAUX; YAMASHITA, 2004; WOMACK; JONES, 2005). Da mesma forma, Zarifian (2001b) sustenta que é fundamental identificar o(s) destinatário(s) do serviço, para que se estabeleça uma relação dialógica entre o prestador - o perito criminal - e os destinatários do serviço, a fim de lhes entregar valor. A partir da identificação dos públicos do serviço, discute-se o seu processo de produção, a intangibilidade do serviço e, finalmente, o seu valor.

\section{$4 \mathrm{O}$ processo de produção do serviço}

O serviço é complexo, pois tem interfaces com as esferas técnico-científica, policial e jurídica (MISSE, 2006), lida com eventos (RODRIGUES; RACHID, 2006) e funciona 24 horas por dia e 7 dias por semana, "24/7" (JOHNSTON; CLARK, 2005). No órgão pesquisado, o serviço é dividido em quatorze naturezas periciais distribuídas em perícias externas e internas. As primeiras são as de: crimes contra a vida, crimes contra o patrimônio, acidentes de trânsito, engenharia e meio-ambiente. As segundas são constituídas pelos exames especializados (áudio e vídeo, informática, contábeis, documentoscopia e papiloscopia) e laboratoriais (química e física, biologia e bacteriologia, balística e toxicologia). Estas quatorze naturezas periciais permitem 139 tipos de exames diferentes e refletem a variedade do serviço. O serviço de perícia criminal se enquadra na categoria dos serviços profissionais, nos termos discutidos e propostos por Caulliraux et al. (2004), Caulliraux, Proença e Lyra Da Silva (2004) e Mintzberg (2009).

Em Minas Gerais o serviço cobre todo o Estado. $\mathrm{Na}$ capital, o atendimento é realizado pelo Instituto de Criminalística (IC), onde o serviço é dividido em seções especializadas, uma para cada natureza pericial. No interior, o serviço é distribuído em 60 Seções de Criminalística, onde cada uma atende a, um conjunto de cidades. Estas seções estão alocadas em 51 Delegacias Regionais de Polícia Civil e em nove Postos de Perícias Integradas (PPIs), onde funcionam seções de criminalística e postos médico-legais. No interior, ao contrário da capital, o perito faz todos os tipos de exames, exceto os laboratoriais e especializados e, em razão desta multifuncionalidade, são apelidados de 'clínicos gerais'. A multifuncionalidade e o compartilhamento de espaço com as Delegacias de Polícia são formas de gerenciar capacidade (FITZSIMMONS, J. A.; FITZSIMMONS, M. J., 2005) e, assim, atender a todo o interior. Na maioria das seções, não há funcionários de apoio e, em muitas, os peritos comparecem aos locais sozinhos, mesmo durante a noite. O quadro de peritos criminais passou de $472 \mathrm{em} 2000$ para 581 em 2007, um aumento de $23 \%$; enquanto o número de atendimentos no mesmo período passou de 76.488 para 150.916, um aumento de $97 \%$.

\subsection{O processo de produção do serviço de perícia criminal}

O processo é o script (VOSS; ZOMERDIJK, 2007) do serviço. O processo de produção do serviço (Figura 3) começa com o acionamento da perícia pelo delegado de polícia, realizado por meio do Centro Integrado de Atendimento e Despacho na capital e pelas Delegacias de Polícia no interior. Após o acionamento, o perito identifica a natureza pericial, seleciona o material apropriado e se dirige para o local. Este tempo de deslocamento varia em função da distância, das condições climáticas e da pista. Há cenas de crime que estão próximas à sede, enquanto outras, a mais de $200 \mathrm{~km}$. Portanto, o front office do serviço segue um arranjo posicional (SLACK; CHAMBERS; JOHNSTON, 2002; WILD, 2003; CORRÊA; CAON, 2002), pois os peritos transportam para a cena do crime todo o material específico necessário.

No local, genericamente, o perito criminal verifica se este está preservado pela polícia, que às vezes utiliza fita de isolamento. Caso haja alterações, ele as registra. A preservação do local é um fator crítico para o sucesso do trabalho pericial. Na sequência, o perito faz uma vistoria preliminar, elabora o seu plano de ação e faz as anotações. Busca os vestígios (impressões digitais, sangue, fios de cabelo, objetos, rachaduras, cadáveres, rompimento de obstáculos, etc.) conforme o evento e os fotografa. Efetua as medições e desenha um croqui. Coleta os vestígios com a técnica apropriada, identifica-os e os preserva. Finalmente, libera o local. Retorna à seção de origem e registra o atendimento (JAMES; NORDBY, 2005; FISHER, 2004; CÓDIGO..., 2005, art. 158-184; Observação direta). 


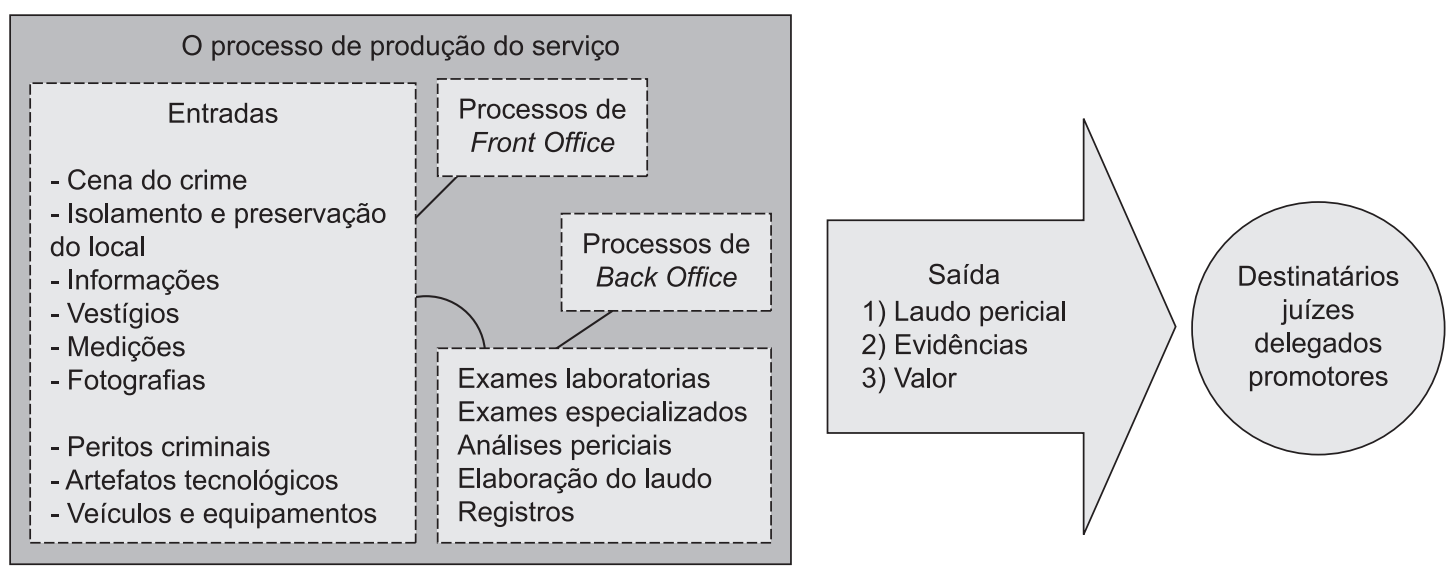

Figura 3. Processo simplificado do serviço de perícia criminal. Inspirado em Johnston e Clark (2005, p. 175).

Os vestígios coletados são submetidos a exames complementares (DNA, residuográfico, papiloscópicos, microcomparação balística, arquivos digitais, toxicológicos, etc.), que são requisitados pelo próprio perito ao laboratório ou à seção especializada, e, se tiverem relação com o delito, tornam-se evidências. É comum, durante as investigações, a polícia solicitar para eventuais suspeitos o fornecimento de padrões (sangue, fio de cabelo, impressões digitais, caligrafia, etc.), para que sejam comparados e analisados com aqueles vestígios que o perito criminal coletou no local. Esses exames são realizados no back office, centralizados na capital, porque são poucos os postos do interior que realizam alguns deles. Os peritos do back office ao final emitem um laudo, que é encaminhado ao perito do caso.

Posteriormente, há a elaboração do laudo, outro fator crítico. O laudo descreve em detalhes a cena do crime, analisa e interpreta as evidências e a dinâmica dos fatos. Ao final, é emitida uma conclusão. O laudo contém fotografias e croquis para ilustrar o local e as evidências e fundamentar as conclusões. Enfim, documenta a prova pericial ou material. A priorização tanto do atendimento quanto da elaboração do laudo segue, em geral, a regra do "[...] caso mais crítico primeiro." (JOHNSTON; CLARK, 2005, p. 267). Após a sua finalização, o laudo é encaminhado à Delegacia de Polícia, ou juízo, que o requisitou. Após o juiz aceitar a denúncia do promotor, e desde que o perito tenha finalizado o laudo, as partes poderão constituir assistentes técnicos para analisá-lo. Os peritos também podem ter que responder a quesitos escritos ou serem intimados a comparecer pessoalmente perante o tribunal para prestar esclarecimentos sobre o laudo pericial ao juiz, ao promotor e aos advogados.

\section{Da tangibilidade da evidência à intangibilidade da prova pericial}

Segundo Andreasen e Kotler (2007, p. 197), serviço é “[...] essencialmente intangível." Segundo Giannakis (2001),

[...] todos os pesquisadores admitem que a característica central dos serviços é a noção de intangibilidade, porque o resultado de muitos serviços pode não ser algo tangível. Pode ser um desempenho, um processo, ou uma ação, que não transmita a propriedade.

Embora seja a diferença mais citada entre produtos e serviços, para Lovelock e Gummesson (2004), a intangibilidade nem sempre fica clara nas análises sobre serviço.

O valor de um serviço é intangível, na medida em que seus resultados são imateriais. Não podendo ser fisicamente percebidos, pelos sentidos básicos do ser humano, devem ser apreendidos mentalmente (SILVA; LANCMAN, 2009). A intangibilidade influencia o modo como uma organização de serviços é gerenciada e impacta na sua avaliação, na estratégia e no processo de produção do serviço (BOWEN; FORD, 2002, CORREAA; CAON, 2002).

Há que se distinguir entre o nível de intangibilidade do resultado do serviço e o do processo de produção (GIANNAKIS, 2001). O primeiro consiste na essência da prestação e a intangibilidade varia em função da natureza dos elementos que são disponibilizados, podendo ser ativos (materiais, humanos, financeiros, tecnologia) - mais tangíveis -, ou informação, conhecimento - mais intangíveis. O resultado da perícia tem dois lados: um lado tangível, que são as evidências coletadas na cena do crime; e outro intangível, que são as descrições, análises, interpretações, demonstrações, abstrações e conclusões, enfim, as informações contidas no laudo pericial. A intangibilidade do 
processo de produção varia dos elementos tangíveis, tais como equipamento e pessoal, que facilitam o desempenho ou comunicação do serviço, até a ausência de evidências. O processo de produção pericial tem como elementos tangíveis o pessoal, os artefatos tecnológicos e outros equipamentos utilizados para realizar o trabalho; e como intangíveis, a forma de atuar do perito na cena do crime e o processo de produção intelectual para construção do laudo.

Ainda dentro desta questão, o cenário em que o serviço é prestado, juntamente com o comportamento dos atores do serviço, comunica o valor do serviço que o diferencia de outros semelhantes (BOWEN; FORD, 2002; VOSS; ZOMERDIJK, 2007). Compõem o cenário da perícia criminal: - o local isolado com a fita; o jaleco do perito; as maletas com a inscrição "Crimes contra a Vida" ou "Crimes contra o Patrimônio", contendo kits próprios; os artefatos tecnológicos; a lupa; a forma de atuação do perito, meticulosa e cuidadosa; o veículo com o logotipo; os vestígios; entre outros. Esta questão é chave, porque no cenário há um dos encontros (o outro é no laudo) entre a intangibilidade da aura da ciência e a tangibilidade dos vestígios encontrados. É com o racional que se buscam os vestígios, porque se revolver ou destruir a cena do crime, o perito não encontra prova. A intangibilidade do serviço do perito não é o resultado em si, mas o impacto na mente das pessoas, que associam este cenário à precisão e à legitimidade da ciência.

De fato, pode-se dizer, à maneira dos autores institucionalistas (POWELL; DIMAGGIO, 1991; SELZNICK, 1957; SCOTT, 1987), que a perícia busca aumentar a credibilidade do processo da justiça, mediante o uso de práticas científicas, e é precisamente nesse ponto que se pode reconhecer a intangibilidade do trabalho pericial. Em outras palavras, a Justiça, tal qual qualquer organização, depende da aceitação da sociedade na qual ela opera, e a perícia contribui nessa questão.

\section{Valor}

O objetivo da rede interorganizacional integrada pela perícia é entregar um valor básico de Justiça. Assim, partiu-se do princípio de que os integrantes da rede compartilhassem o mesmo conceito de 'Justiça Criminal'. Inicialmente, buscou-se, nos websites do Tribunal de Justiça, da Polícia Civil e do Ministério Público, todos de Minas Gerais, e também do Supremo Tribunal Federal, o conceito de 'Justiça Criminal'. Porém, este conceito não foi encontrado, fato que causou estranheza. A existência de um conceito claro e compartilhado, permeando esta rede, em tese, facilitaria a coordenação e a integração dos atores.

Conforme já visto, os principais destinatários do serviço pericial são os juízes de direito, delegados de polícia e promotores públicos. Então, pesquisou-se "Qual o valor do serviço de perícia criminal para os principais destinatários do serviço?". Acrescentou-se um defensor público, porque o serviço impacta profundamente a defesa.

Adotou-se a abordagem de valor proposta por Zarifian (2001b), porque ela penetra no âmago da relação entre os prestadores e os públicos do serviço. Aborda, além do valor de utilidade, questões como os valores de justiça e solidariedade, que são essenciais a um serviço público. Portanto, trata-se de uma abordagem mais apropriada para analisar um serviço, como a perícia criminal. Para Zarifian (2001b, p. 102-119), serviço é:

[...] uma organização e uma mobilização, o mais eficiente possível, de recursos para interpretar, compreender e gerar a mudança perseguida [...] nas condições de atividade do destinatário, cujas consequências (efeitos) são consideradas válidas e positivas por este último e/ou pela coletividade.

O modelo proposto aborda valor a partir das consequências (dos efeitos, dos resultados) do serviço sobre as condições de atividade dos destinatários e a partir da eficiência no uso dos recursos necessários para produzi-las. Neste caso, "[...] a definição pelas consequências dirige a definição pelos recursos." (ZARIFIAN, 2001b, p. 103). A organização do serviço visa interpretar, compreender e produzir a transformação nas condições de atividade do(s) destinatário(s). Para Zarifian (2001b, p. 103),

[...] o valor é avaliado no ponto em que dois julgamentos se encontram: um sobre a validade dos resultados produzidos pelo serviço, e outro sobre a eficiência dos recursos mobilizados para produzir ditos resultados.

ou seja, um serviço não pode ser produzido a qualquer custo. A avaliação do serviço pelo destinatário consiste de três elementos: as expectativas, o que se espera do serviço; as consequências, ou em que medida os resultados atenderam às expectativas; e o processo de produção, em que há o encontro do resultado e da mobilização de recursos (ZARIFIAN, 2001b).

Analisar-se-á primeiramente o valor de serviço a partir das consequências, para, então, analisá-lo do ponto de vista dos recursos necessários para produzi-las, quando será realizada a integração das duas abordagens, conforme proposto por Zarifian (2001b).

\subsection{O valor do serviço a partir das consequências nas condições de atividade do destinatário}

A partir da transformação produzida pelo serviço na condição de atividade do destinatário é que se pode 
avaliar as consequências produzidas pelo serviço. Porque o "[...] serviço é o efeito, o resultado, nas condições de exercício da atividade." (ZARIFIAN, 2001b, p. 105) do destinatário. Na perícia criminal, o serviço prestado não é o levantamento de local, nem os exames laboratoriais e/ou especializados, ou a elaboração do laudo; estes são os meios. O serviço são as consequências, os efeitos, os resultados das informações contidas no laudo nas condições de atividade dos destinatários, ou seja, nas investigações conduzidas pelos delegados de polícia, nos atos de denunciar e processar dos promotores públicos e nas sentenças dos juízes, para que se promova Justiça. Para avaliar estas consequências do serviço, Zarifian (2001b) propõe quatro dimensões: utilidade, justiça, solidariedade e estética.

\subsubsection{A avaliação de utilidade}

A utilidade consiste na "[...] transformação das condições de atividade do destinatário do serviço." (ZARIFIAN, 2001b, p. 106), por meio da produção de resultados positivos para ele. O serviço pericial pode agir sobre as condições de atividade dos destinatários, mas não sobre a própria atividade, porque esta depende da competência profissional de cada um. Os peritos criminais podem ter realizado um levantamento de local e produzido um laudo pericial de qualidade, mas o resultado sempre dependerá do uso que os delegados de polícia, promotores, advogados e juízes fizerem dele, a partir da respectiva competência profissional de cada um.

Um delegado de polícia afirmou que "a perícia é a lente que nós temos "[...] 90\% do trabalho do delegado no relatório é baseado na perícia." Para o promotor de justiça,

[...] o laudo é essencial ao nosso trabalho... um bom laudo facilita muito o trabalho do Ministério Público... num júri, por exemplo, o laudo com fotografias da vítima ajuda muito a convencer os jurados, porque se não fica uma coisa abstrata, virtual.

Em um júri de três rapazes acusados de estuprar e matar uma mulher, o promotor afirmou que "a vítima não pode falar, porque foi assassinada. Mas o laudo pericial falou por ela”. Um juiz de direito exemplificou como o serviço pericial interfere nas condições da sua atividade:

Um acidente de trânsito na estrada, em um carro tinha o motorista com a esposa. A esposa não viu nada, porque estava dormindo. O motorista, marido, morreu; e do outro lado estava o pretenso culpado. Então, não tinha prova testemunhal. É uma condenação, que foi articulada através dos elementos que foram levados ao processo pelo perito [...] Nós tivemos aqui um crime de moeda falsa. Um estudante... começou a fabricar notas, notas altas... ficou muito parecido... foi um tipo de crime que (a sentença) foi baseada exclusivamente na prova pericial, porque o indivíduo negou. Falou que um amigo havia passado para ele, que, consequentemente, ele estava passando. A prova pericial primeiro foi para constatar a falsidade da moeda. Através de um mandado de busca e apreensão se fez a apreensão do computador dele e da impressora. Aí foi feita a prova pericial no computador e na impressora. $\mathrm{O}$ perito chegou à conclusão que aquele trabalho era exatamente daquela impressora, encontraram alguns vestígios dentro do computador, ele foi abrindo os arquivos, embora tivessem senhas bloqueando, ele conseguiu desbloquear. E a prova praticamente foi feita com a perícia, não tinha testemunha de quem fabricou a nota. Houve condenação [...] Tive o caso de um taxista. Foi famoso na época, que quem o matou foi a amante dele. Também não tinha testemunhas. Ela foi auxiliada por uma pessoa. A vítima foi levada para o mato. A prova pericial foram pegadas de um homem, de mulher, através do calçado, tinha resquícios de comida, tinha pano rasgado, e através desta prova pericial, houve comparações e se chegou à amante [...] Se não fosse a prova pericial, os dois primeiros casos seriam casos de absolvição na certa, por insuficiência de provas; no terceiro seria dificultoso (a condenação).

Estes casos dão o significado para o juiz, para o promotor e para os delegados do valor de utilidade do serviço da perícia, principalmente, provar a materialidade do delito e vincular o autor ao crime. Pode-se resumir em dois blocos: 1) fornece uma versão do fato investigado, uma narrativa com começo, meio e fim, em que os acontecimentos são dispostos em uma sequência lógica, e que permite reconhecer causas e consequências; 2) fornece provas e argumentos para convencer os diferentes atores de que essa versão é a verdadeira. Para entregar este valor de serviço, é necessário não só dominar a atividade técnica, para elucidar fatos, mas também compreender o trabalho dos destinatários do serviço, para produzir argumentos válidos para a situação.

\subsubsection{A avaliação de justiça e de solidariedade}

A avaliação de justiça pressupõe cumprir o princípio da igualdade e universalidade do acesso ao serviço. O valor de justiça é intrínseco aos serviços públicos no sentido de permitir o acesso igual a todos e, portanto, tem que prever as condições para que as pessoas o utilizem efetivamente, independente de suas condições econômicas e sociais. Para isto, a oferta deve ser flexível (ZARIFIAN, 2001b), pois 
o processo de produção do serviço deve se adequar às condições do usuário. Na perícia criminal, esta avaliação se aplica para as vítimas e/ou parentes e àqueles erroneamente acusados, que estão entre os beneficiários do serviço. A flexibilidade é da própria natureza do serviço, haja vista que cada caso recebe o tratamento apropriado. Entretanto, a capital e algumas seções do interior dispõem de mais recursos tecnológicos, o que favorece uma prestação de maior qualidade.

A solidariedade do serviço consiste em verificar se ele contribui para a inclusão social de segmentos marginalizados da sociedade. Segundo Zarifian (2001b, p. 115), “[...] prestar serviço é agregar uma decisão de solidariedade a um ato ou a uma produção concreta endereçada ao outro".

Um dos papéis da perícia é evitar que as pessoas, principalmente aquelas excluídas, sejam submetidas a constrangimentos para confessar crimes, que muitas vezes não cometeram. Neste aspecto, o defensor público afirmou que já utilizou laudos periciais para desclassificar o crime de uma acusação (dar ao crime uma gravidade menor), ou até mesmo, permitir a absolvição. Houve casos em que um inocente estava sendo erroneamente acusado: "são pessoas que se não fosse a defensoria pública e o trabalho da perícia criminal, fatalmente, seriam condenadas" (Defensor Público).

Dito de outra forma, a perícia criminal não é órgão de acusação nem de defesa. A isenção e a busca da verdade são dimensões de solidariedade intrínsecas ao serviço e, por esta razão, os peritos estão sujeitos aos mesmos impedimentos dos juízes. Ambas as avaliações - justiça e solidariedade - se relacionam com a questão dos direitos humanos, em que a perícia criminal desempenha um papel crítico, conforme exemplifica um perito criminal:

[...] a perícia é uma promotora dos direitos humanos. Por exemplo, no momento em que ela diz que uma pessoa, que está presa por uma acusação de estupro, tem o seu DNA excluído do grupo suspeito e essa pessoa é solta. Então, você tem muitos casos de realmente promover cidadania por meio da prova técnica (Perito Criminal).

Durante a pesquisa, observou-se uma tendência de dar mais atenção e de se priorizar casos segundo o critério do "[...] cliente mais valioso." (JOHSNTON; CLARK, 2005, p. 267), isto é, que envolvam pessoas importantes ou casos que tenham maior repercussão na mídia. Outra constatação importante, é que, por deficiência de recursos, não são feitos todos os exames, mesmo que isso contrarie a legislação (CÓDIGO..., 2005, art. 158). Por exemplo, a perícia não é realizada em alguns locais de furto de objetos de pequeno valor por meio da prática de arrombamento em residências, quando não há suspeitos. Estes fatos atingem principalmente os segmentos marginalizados da sociedade. E acabam invertendo os valores da avaliação de justiça do serviço, que "[...] têm o dever de ser específica, de considerar pessoas reais, singulares e diversificadas." (ZARIFIAN, 2001b, p. 110) e de solidariedade, na medida em que não contribuem para a inserção social, preconizada pelo autor.

Entretanto, os destinatários do serviço pericial têm poder na rede interorganizacional da qual fazem parte, são especialistas em direito e dispõem de meios legais para garantir que o serviço atenda a suas respectivas expectativas. Podem requerer exames, formular quesitos e convocar os peritos, para corrigir eventuais falhas do serviço, fazendo com que haja um duplo controle sobre o serviço: o da gerência e o dos destinatários (KORCZYNSKI et al., 2000).

\subsubsection{Não basta ser bom, tem que ser belo}

A avaliação estética é "[...] um misto de avaliação de beleza e de avaliação ética, um misto de belo e do bom." (ZARIFIAN, 2001b, p. 116). Trata-se de uma avaliação subjetiva. É relevante porque a produção de um serviço é "[...] a produção de sua exposição para um público." (ZARIFIAN, 2001b, p. 117). Segundo o autor, a avaliação pertence ao destinatário do serviço e é compartilhada entre ele e o prestador de serviço. O valor estético do serviço de perícia criminal está na produção de provas, sem que seja necessário submeter as pessoas a constrangimentos, ou seja, respeitando-se os direitos humanos e, ainda, auxiliando a polícia e a justiça a encontrar a verdade, inclusive em crimes em que não haja testemunhas presenciais.

\subsection{O valor do serviço a partir dos recursos}

O valor do serviço a partir dos recursos é condicionado pelas consequências (ZARIFIAN, 2001b). Em outras palavras, a eficiência se subordina à eficácia. Para dimensionar os recursos necessários, é preciso identificar, conhecer e compreender a atividade do destinatário e suas expectativas sobre o resultado a ser gerado. Isto demanda uma competência profissional, que "consiste em construir uma interpretação das consequências a serem produzidas para o cliente a partir do que ele mesmo propõe, mas também a partir de informações que espelham outras perspectivas" (ZARIFIAN, 2001b). Esse autor propõe uma comunicação habermasiana entre o prestador e o destinatário, ou seja, uma relação dialógica entre ambos, para o prestador conhecer melhor a atividade do destinatário.

Assim, a competência técnico-científica do perito criminal é essencial na prestação do serviço, mas não o suficiente. Para gerar valor, é preciso conhecer a 
atividade do destinatário do serviço, ou seja, o perito precisa conhecer o trabalho do juiz de direito, do delegado de polícia, do promotor de justiça e do advogado, para saber onde o laudo pericial tem que chegar ao final. É necessário que o perito criminal saiba como o laudo é utilizado pelos principais destinatários do serviço e o valor da contribuição do laudo para a atividade de cada um deles. Enfim, "[...] penetrar na 'caixa preta' que constitui a atividade do destinatário." (ZARIFIAN, 2001b, p. 120). Mas, neste caso, não é tão simples, porque a comunicação entre o perito criminal e os principais atores da rede é predominantemente escrita e realizada por meio de requisições, ofícios e quesitos. Portanto, instrumental. Este fator faz com que estes atores não se conheçam o suficiente. Em Minas Gerais, este fato é agravado, porque a comunicação entre o perito criminal e os públicos externos à Polícia Civil, tais como juízes e promotores, ainda é mediada pelos delegados de polícia.

Assim, a partir do envio do laudo ao inquérito, ou processo, o perito não tem mais conhecimento das consequências do caso: "eu gostaria de saber o que deu." (Perito Criminal). Como é possível conhecer o valor para os destinatários sem saber o resultado de um determinado serviço? Para isto é necessária uma maior aproximação dos peritos criminais com os destinatários do serviço, para que o laudo pericial entregue mais valor.

Entre as competências necessárias ao desempenho da atividade pericial estão as habilidades, tanto para buscar e coletar os vestígios na cena do crime, quanto para conduzir os exames dos vestígios e as respectivas análises probatórias articuladas no laudo pericial, ambas legitimadas pelo conhecimento científico e pela tecnologia utilizada. Ambas estão imbricadas, a segunda engloba a primeira. Há um perito que examina a cena do crime, coleta os vestígios e os encaminha para o back office, para exames laboratoriais e/ou especializados, onde outro perito procederá aos exames necessários e retornará o resultado ao perito do local, para que ele possa concluir o laudo. O ideal é que fosse o mesmo perito, ou que pelo menos ele tenha uma visão do todo. Assim, o perito do laboratório precisa conhecer o processo de cena do crime e o de cena do crime entender o processo do laboratório, para que ele possa manusear e coletar os vestígios de forma apropriada. E ainda, o perito criminal precisa ter competências para sustentar oralmente o laudo pericial em juízo no tribunal, além das relacionais já abordadas.

Em Minas Gerais, os recursos humanos são recrutados entre brasileiros portadores de curso superior e selecionados por meio de concurso público de provas e títulos. Os aprovados frequentam a Academia de Polícia Civil para um curso de formação com duração média de 720h, que inclui legislação e formação policial e profissionalizante. Ao final do curso, são nomeados e designados para o serviço. Posteriormente, farão cursos de aperfeiçoamento, de chefia policial e outros específicos. No País, observou-se uma diversidade nos processos de recrutamento, seleção e formação dos peritos criminais, dependendo da unidade da federação.

A perícia criminal aplica diversos artefatos tecnológicos, que constituem importante recurso para auxiliá-la. Afinal, na investigação, "o microscópio está substituindo o pau de arara.” (Perito Criminal). Para Zarifian (2001b),

[...] o processo inteiro de produção de serviço pode ser analisado como uma forma de mobilização de um conjunto convergente de competências e recursos, no qual a ferramenta tecnológica é o auxiliar e suporte desse processo."

Assim, a competência profissional é o recurso principal, enquanto que os artefatos tecnológicos são auxiliares e servem de suporte à competência no processo de produção do serviço e para entregar valor. $\mathrm{O}$ perito não é mero expectador, nem coadjuvante da tecnologia; é ele quem dirige a sua aplicação no caso concreto.

Os principais recursos tecnológicos disponíveis no órgão pesquisado foram: - laboratório para realização de exames de DNA (define perfil genético e estabelece vínculo genético entre dois indivíduos a partir de um padrão para comparação do ácido desoxirribonucleico - DNA); Evo Finder (sistema computacional que contém um banco de dados, para auxiliar a análise de projéteis de arma de fogo coletados na cena do crime); Imaquest/Identquest (softwares que auxiliam na análise de impressões digitais coletadas em cenas de crime, permitindo a comparação com um padrão suspeito); reagentes químicos, como o luminol, que revela a presença de sangue; câmeras digitais; microscópio estereoscópico digital para comparação (balística, fibras, etc.); pós para levantamento de impressões digitais; luz forense (emite luz ultravioleta e detecta material de natureza fisiológica); cromatografia gasosa (permite a separação de substâncias de um material suspeito, submetido a exames); espectrógrafo infravermelho; GPS; maletas, contendo kits de coleta de vestígios; software para comparação de voz; hardware e softwares diversos; entre outros. Portanto, são várias inovações tecnológicas aplicadas à perícia criminal, que exigem treinamento específico e competência dos peritos criminais para incorporá-las.

\subsection{O valor intangível do serviço é construído a partir de evidências e procedimentos tangíveis}

A princípio, legalmente, não há hierarquia de provas e o juiz formará sua convicção pela livre apreciação das provas produzidas legalmente no 
processo (CAPEZ, 2003; NUCCI, 2006). Para Capez (2003), a prova pericial "representa um plus em relação à prova e um minus em relação à sentença". A intangibilidade do serviço inclui a importância que o Juiz (e a sociedade) dá à cientificidade do trabalho do perito e esse valor intangível do serviço é construído por meio de procedimentos e evidências tangíveis.

Um estudo realizado na comarca de Cuiabá (FACHONE et al., 2007) analisou as sentenças em acidentes de trânsito e concluiu que os juízes davam maior valor à prova pericial. O defensor público afirmou que em um de seus casos, embora contasse com várias testemunhas contradizendo o laudo pericial, o juiz decidiu única e exclusivamente com base no laudo pericial. Portanto, verificou-se uma tendência de se valorizar mais a prova pericial. Assim, busca-se, por meio da perícia, apropriar-se dos avanços da ciência e aportá-los tanto na investigação quanto no processo criminal, para respaldar e legitimar as sentenças judiciais.

\section{Conclusões}

$\mathrm{O}$ presente artigo mostrou que a perícia criminal desempenha um papel relevante na rede interorganizacional de segurança pública e justiça criminal. O valor essencial do serviço é fazer o link entre a ciência e a justiça. $\mathrm{O}$ valor para a sociedade é conciliar o interesse social de que haja uma apuração eficaz dos delitos, com o respeito aos direitos humanos. Em julgamentos criminais, os juízes entrevistados destacam a objetividade e a imparcialidade da prova pericial. A partir das análises, inferiu-se que esta imagem de objetividade e imparcialidade se deve à associação com a ciência. A Justiça tem como valor central a imparcialidade ("A Justiça é cega"), e a perícia contribui para a operacionalização deste valor.

Em serviços, uma questão difícil de lidar é com a intangibilidade, porque ela não é objetiva, é ambígua. Quanto mais intangível um serviço, mais difícil de avaliar. A dualidade entre os resultados tangíveis (evidências) e intangíveis (informações contidas no laudo pericial) do serviço, quanto à tangibilidade (pessoal, artefatos tecnológicos, equipamentos) e a intangibilidade (cenário) presente no processo pericial, induz à reflexão sobre a objetividade, a imparcialidade e a legitimidade da ciência. É no cenário (cena do crime) e no laudo pericial que se encontram a tangibilidade e a intangibilidade do serviço. As evidências tangíveis só são válidas porque elas são legitimadas pela ciência. Pela mesma razão, as informações contidas no laudo pericial são utilizadas pelos juízes, para fundamentação das sentenças judiciais criminais.

Os principais recursos do serviço são as competências dos profissionais oriundos de diversos campos do conhecimento, e os artefatos tecnológicos, que os auxiliam no desempenho de suas atividades. Há dois grupos de competências. No primeiro são as técnicas, que consistem em localizar e coletar vestígios na cena do crime, incorporar novas tecnologias, proceder aos exames complementares laboratoriais e/ou especializados, realizar análises científicas com base nos vestígios coletados e emitir conclusões úteis aos destinatários do serviço. No segundo, estão as relacionais, que são essenciais para se construir o valor do serviço. Ressalte-se que as análises mostraram que, para entregar valor, só as competências técnicas não são suficientes, é preciso conhecer a atividade dos destinatários do serviço. Entretanto, uma descoberta da pesquisa chama a atenção: a comunicação dos peritos com os destinatários do serviço é predominantemente instrumental. Esta forma de comunicação dificulta o conhecimento das atividades dos destinatários e, consequentemente, do que seja valor para eles. Portanto, a aproximação dos peritos com os destinatários do serviço, principalmente juízes e promotores públicos, para a construção de uma relação dialógica, é essencial à criação de valor nesta rede. Além disso, a falta de um conceito único e explícito de Justiça Criminal para todos os atores cria dificuldades de coordenação e integração desta rede.

Finalizando, a partir da definição do valor que o serviço de perícia criminal deve entregar, sugerem-se pesquisas sobre as formas de organizar o serviço. Este artigo abordou de modo introdutório as competências para o exercício da atividade de perito criminal. Assim, sugerem-se novas pesquisas para mapear estas competências e a sua relação com a entrega de valor e a organização do serviço.

\section{Referências}

ANDREASEN, A. R.; KOTLER, P. Strategic marketing for nonprofit organizations. $7^{\text {th }}$ ed. Upper Saddle River: Pearson Education, 2007. 504 p.

BOWEN, J.; FORD, R. C. Managing service organizations: does having a "thing" make a difference? Journal of Management, v. 28, n. 3, p. 447-469, 2002.

BRASIL. Constituição da República Federativa do Brasil. Brasília, DF: Senado Federal, 1988.

BRASIL. Lei 11.690, de 9 de junho de 2008. Altera dispositivos do Decreto-Lei $\mathrm{n}^{\circ} 3.689$, de 3 de outubro de 1941 - Código de Processo Penal, relativos à prova, e dá outras providências. Disponível em: <http://www. planalto.gov.br/ccivil/_Ato2007-2010/2008/Lei/L11690. htm>. Acesso em: 09 jun. 2008.

BRESSER PEREIRA, L. C. Reforma da gestão e avanço social em uma economia semi-estagnada. Revista de Administração Pública, v. 38, n. 4, p. 543-560, 2004.

CAPEZ, F. Curso de processo penal. 10. ed. São Paulo: Saraiva, 2003. 650 p. 
CAUCHICK MIGUEL, P. A. A adoção do estudo de caso na engenharia de produção. In: CAUCHICK MIGUEL, P. A. (Org.). Metodologia de pesquisa em engenharia de produção e gestão de operações. Rio de Janeiro: Elsevier, 2010. cap. 6, p. 129-143.

CAULliRAUX, H. M. et al. Eixo: "Modelo de gestão organizacional”. 2004. Produto 05: Relatório de Análise Preliminar dos Trabalhos. Disponível em: <http://www. dhnet.org.br/redebrasil/executivo/nacional/anexos/ gestao_org_caulliraux.pdf $>$. Acesso em: 11 out. 2008.

CAULLIRAUX, H. M.; PROENÇA, A. Gestão: introdução conceitual. In: CAULLIRAUX, H. M.; YUKI, M. (Org.). Gestão pública e reforma administrativa. Rio de Janeiro: Lucerna, 2004. cap. 1, p. 19-28.

CAULLIRAUX, H. M.; PROENÇA, A.; LYRA DA SILVA, B. B. Gestão pública no Brasil. In: CAULLIRAUX, H. M.; YUKI, M. (Org.). Gestão pública e reforma administrativa. Rio de Janeiro: Lucerna, 2004. cap. 3, p. 59-78.

CAULliRAUX, H. M.; YAMASHITA, E. C. Gestão Pública. In: CAULLIRAUX, H. M.; YUKI, M. (Org.). Gestão pública e reforma administrativa. Rio de Janeiro: Lucerna, 2004. cap. 2, p. 29-56.

CÓDIGO de Processo Penal. São Paulo: Saraiva, 2005.

CORRÊA, H. L.; CAON, M. Gestão de serviços: lucratividade por meio de operações e de satisfação dos clientes. São Paulo: Atlas, 2002. 479 p.

FACHONE, P. et al. Laudo pericial e sentença: há convergência? In: CONGRESSO NACIONAL DE CRIMINALÍSTICA, 19., 2007, Salvador. Anais... Salvador: Associação Brasileira de Criminalística, 2007. 1 CD-ROM.

FISHER, B. A. J. Techniques of crime scene investigation. $7^{\text {th }}$ ed. Flórida: CRC, 2004.

FITZSIMMONS, J. A.; FITZSIMMONS, M. J. Administração de serviços: operações, estratégia e tecnologia da informação. 4. ed. Porto Alegre: Bookman, 2005. $600 \mathrm{p}$.

GIANNAKIS, M. Supply chain management and the role of inter-organizational relationships in service organizations. In: Annual Conference of the Production and Operations Management Society, 12., Flórida, 2001. Proceedings... Flórida, 2001.

HATCH, M. J.; CUNLIFFE, A. L. Organization theory: modern, symbolic and postmodern perspectives. $2^{\text {nd }}$ ed. New York: Oxford University Press, 2006.

HOOD, C. A public management for all seasons? Public Administration, v. 69, p. 3-19, 1991.

JAMES, S. H.; NORDBY, J. J. Forensic Science: an introduction to scientific and investigative techniques. 2. ed. Florida: CRC, 2005.

JOHNSTON, R.; CLARK, G. Service operations management: improving service delivery. $2^{\text {nd }}$ ed. London: Prentice Hall, 2005.

KIRLIN, J. J. What government must do well: creating value for society. Journal of Public Administration Research and Theory, v. 6, n. 1, p. 161-185, 1996.
KORCZYNSKI, M. et al. Service work in consumer capitalism: customers, control and contradictions. Work, Employment \& Society, v. 14, n. 4, p. 669-687, 2000.

LOVELOCK, C.; GUMMESSON, E. Whither services marketing? In search of a new paradigm and fresh perspectives. Journal of Service Research, v. 7, n. 1, p. 20-41, 2004.

MARCELINO, G. F. Em busca da flexibilidade do Estado: o desafio das reformas planejadas no Brasil. Revista Brasileira de Administração Pública, Rio de Janeiro, v. 37, n. 3, p. 641-658, 2003.

MATIAS-PEREIRA, J. Administração pública comparada: uma avaliação das reformas administrativas do Brasil, EUA e União Européia. Revista de Administração Pública, Rio de Janeiro, v. 42, n. 1, p. 61-82, 2008.

MINAS GERAIS (Estado). Secretaria de Estado de Planejamento e Gestão. Choque de gestão. Belo Horizonte, 2004. Disponível em: <www.planejamento. mg.gov.br/choque>. Acesso em: 01 jul. 2005.

MINTZBERG, H. Criando organizações eficazes: estruturas em cinco configurações. 2. ed. São Paulo: Atlas, 2009.

MIRABETE, J. F. Código de processo penal interpretado. 7. ed. São Paulo: Atlas, 2000.

MISSE, M. Avaliação da formação e da capacitação profissional dos peritos criminais no Brasil. 2006. Relatório final. Disponível em: <http://www.mj.gov. br/Senasp/pesquisas_aplicadas/anpocs/proj_aprov/ aval_form_capacit_michel.pdf > . Acesso em: 25 mar. 2007.

NUCCI, G. S. Código de processo penal comentado. 5. ed. São Paulo: Revista dos Tribunais, 2006. 1214 p.

OSBORNE, D.; GAEBLER, T. Reinventing Government. $9^{\text {th }}$ ed. New York: Addison-Wesley, 1992. 405 p.

PINTO, L. Experiência vivida e exigência científica de objetividade. In: CHAMPAGNE et al. Iniciação à prática sociológica. Petrópolis: Vozes, 1998. cap. 2, p. 59-106.

POWELl, W.; DIMAGGiO, P. (Ed.). The new institutionalism in organizational analysis. Chicago: Chicago University Press, 1991.

RODRIGUES, C. V.; RACHID, A. Análise de eventos em criminalística: um estudo de caso. In: Encontro Nacional de Engenharia de Producão, 26., 2006, Fortaleza. Anais... Ceará: ABEPRO, 2006. 1 CD-ROM.

SAINT-MARTIN, D. Building the new managerialist state: consultants and the politics of public sector reform in comparative perspective. Oxford: Oxford University Press, 2004.

SCOTT, W. R. The adolescence of institutional theory. Administrative Science Quarterly, v. 32, p. 493-511, 1987.

SELZNICK, P. Leadership in administration. New York: Harper and Row, 1957.

SILVA, M. T. D.; LANCMAN, S.; ALONSO, C. M. D. C. Consequiências da intangibilidade na gestão dos novos serviços de saúde mental. Revista de Saúde Pública, v. 43, p. 36-42, 2009. 
SLACK, N. Operations strategy: will it ever realize its potential? Gestão \& Produção, v. 12, n. 3, p. 317-468, 2005.

SLACK, N.; CHAMBERS, S.; JOHNSTON, R. Administração da produção. 2. ed. São Paulo: Atlas, 2002. 748 p.

STARR, M. K. Changing agendas for operations management. Gestão \& Produção, v. 12, n. 3, p. 317-468, 2005.

VIOLÊNCIA é o principal problema do país para $31 \%$ dos brasileiros. Folha Online, 24 mar. 2007. Disponível em: <http://www1.folha.uol.com.br/folha/brasil/ult96u90610. shtml>. Acesso em: 24 mar. 2007.

VOSS, C.; ZOMERDIJK, L. Inovation in experimental services - an empirical view. In: INNOVATION in services. 2007. p. 97-134. (DTI Occasional Paper, 9).
WEISS, R. S. Learning from strangers: the art and method of qualitative interview studies. New York: Free, 1994. 246 p.

WILD, R. Operations management. $6^{\text {th }}$ ed. London: Thomson Learning, 2003. 870 p.

WOMACK, J. P.; JONES, D. T. Lean solutions: how companies and customers can create value and wealth together. New York: Free, 2005. 355 p.

YIN, R. K. Estudo de caso: planejamento e métodos. 3. ed. Porto Alegre: Bookman, 2005. 212 p.

ZARIFIAN, P. Objetivo competência: por uma nova lógica. São Paulo: Atlas, 2001a. 198 p.

ZARIFIAN, P. Valor, organização e competência na produção de serviço: esboço de um modelo de produção de serviço. In: SALERNO, M. S. (Org.). Relação de serviço: produção e avaliação. São Paulo: SENAC, 2001b. p. $97-149$. 